\title{
From community to public ownership: a tale of changing accountabilities
}

\begin{abstract}
Purpose: To examine changes in accountability as the provision and control of education moved from private nonprofit organisations to a public sector provider.

Methodology: Analysis of nineteenth century archival documents from significant primary educational providers in a major early New Zealand settlement.

\section{Findings:}

The nonprofit education provider utilised public meetings including public examinations, whose effect was to develop trust based on the education values it shared with its community of stakeholders. It also published financial reports which, along with inspections and statistical returns, were preferred once the government became the education provider. Such publications and inspections indicated bureaucracy and control. Nevertheless, government funding, rather than the nonprofit organisation's dependence on its community, made education provision sustainable.
\end{abstract}

\section{Research implications:}

It has been suggested that the differences between public sector and private sector accounting and accountability are not always sharply defined (Carnegie and Napier, 2012). However, this case study shows that a change of education provider did lead to a marked difference in accountability. While theory suggests that public sector accountability should enhance democracy, the party best meeting this brief was the nonprofit provider, with the public sector provider preferring hierarchical accountability. It could be argued that funding dependence drove these different approaches as community accountability was traded for financial security.

Originality/Value: Distinctive study of accountability practices to external stakeholders, in a mid-nineteenth century education context.

Key Words: Accountability, nonprofit, public sector, education.

Paper type: Research paper. 


\section{From community to public ownership: a tale of changing accountabilities}

\section{Introduction}

Accounting history research indicates that organisational practices are influenced by their context. Historical studies also inform current understanding of accounting and accountability (Carnegie and Napier, 2012). Analysis of non-owned organisations, that is, organisations in the nonprofit and public sectors, especially benefit from the study of context and history. There is a growing body of work analysing accountability relationships and practices in these organisations in the current day (for example, Awio, Northcott and Lawrence, 2011; Cordery, Baskerville and Porter, 2010; O’Dwyer and Unerman, 2008). However, analyses of historic practices of accountability in nonprofit or voluntary organisations have been mainly limited to religious organisations, including Quattrone's (2004) study of accountability in the Jesuit community in the $16^{\text {th }}$ and $17^{\text {th }}$ century and Cordery's (2006) analysis of accountability discharged by Methodist missionaries prior to New Zealand's colonial history (1819-1840). Research into the non-denominational organisational field by Fowler (2010) investigates resourcing and accounting within the Nelson School Society (NSS) over a ten-year period (1842-1852) which was before the involvement of local government in education in New Zealand. The present paper builds on that literature and examines accountability changes in the mid-nineteenth century as the provision and control of primary (elementary) education in the newly established settlement of Nelson (New Zealand) moved from private nonprofit organisations to a public sector operation.

Sargiacomo and Gomes (2011) lament the paucity of historical studies of accountability in the public sector, notably local government (especially Anglophone studies). They call for historical research into accounting and accountability inter-relationships between local governments and non-governmental organisations. This paper responds to the need for historical research into inter-relationships between government and non-governmental organisations in an Anglophone country. It also starts to fill a lacuna in research into accountability, particularly the changes in accounting and accountability following organisational 'ownership' change from one sector to another.

Historical research is particularly necessary as "more recent research in this area tends to suggest that sharp distinctions between public sector and private sector accounting are diminishing" (Carnegie and Napier, 2012, p.345). In answer, this paper highlights the differences (and similarities) between public and private nonprofit organisations, analysing changes in accountability as a result of organisational 'ownership' change between nonowned public and private organisations. Further, it adds to the literature on organisational accounting and accountability in its social and economic contexts. The paper uses archival evidence collected from a variety of sources to investigate the accountability relationships and practices employed in Nelson educational organisations and related entities from 1844 until 1859.

New Zealand was established as a British colony with the signing of the Treaty of Waitangi in 1840[1]. Between 1842 and 1843, approximately 3,000 New Zealand Company settlers arrived in the provincial settlement of Nelson, in the North-West of the South Island. During 1842, the New Zealand Company brought approximately 9,000 British settlers to New Zealand, which by the end of that year had a non-Māori population of just less than 11,000. Nelson was the second largest of the New Zealand Company Settlements (New Zealand Year Book, 1990) and was to become one of the six provinces formed under the 1852 Constitution of New Zealand. Nelson's settlers, from a variety of social backgrounds, 
organised primary education in such a way that it became the model for the national primary education system in 1877 (Fowler, 2010).

This paper goes on to discuss accountability theory and the relevant literature on nonprofit and public sector accountability in historical studies. It then describes the accountability relationships and mechanisms used to discharge accountability and the changes occurring in the case study organisations, and examines the resulting differences and similarities. Lastly, the discussion and conclusions are presented, limitations noted and areas for future research suggested.

\section{Accountability - A Review}

\subsection{Accountability theory}

Three key questions underpin accountability: for what is the organisation accountable, to whom is it accountable, and what mechanisms does it use to discharge accountability? Accountability in its broadest sense, as noted by Roberts and Scapens (1985, p.445), is "the giving and demanding of reasons for conduct". Ebrahim (2003, p.194) defines accountability interactions in more detail as the "means through which individuals and organizations are held externally to account for their actions and the means by which they take internal responsibility for continuously shaping and scrutinizing organisational mission, goals and performance."

In nonprofit and public sector organisations, the first key question is for what is an organisation accountable? While for-profit organisations may be accountable for meeting their financial goals, public sector and nonprofit organisations have multiple accountabilities. First, they will be accountable for their financial and other resources (donated or obtained) and second, for meeting the non-financial goals or objectives for which they are established.

The goals or objectives of private nonprofit organisations tend to be 'mission-focused', for instance charities are set up to relieve poverty, or for the dissemination of religion or education, or for other purposes defined by the founders to be for the good of the community. Notwithstanding the need to operate within the legislative environment, nonprofit accountability is perhaps more simply focused (than public sector accountability) on mission delivery.

Public sector organisations also seek to achieve non-financial or social objectives, but, as noted by Mulgan (2003, p.28), these goals are harder "to specify and are a matter of continuing debate and adjustment" in the public arena. As they are publicly funded through coercive taxes and parliament is composed of elected representatives, the views of taxpayers and voters (as well as their representatives) must be taken into account when specifying these goals. Accountability can enhance democratic citizenship through public deliberation and participation, and "contributes directly to the ongoing debate about the public good ... the essential feature of a democratic society" (Mulgan, 2003, p.13). Public sector bureaucracies also need to focus on compliance with legislation, processes and procedures (Mulgan, 2003); indeed, in the historical study of Macias (2002), public sector accountability focused on compliance, yet, following privatisation, the for-profit firm focused on efficiency and financial return. Public sector accountability therefore holds two focuses in tension public servants' legality-compliance and processes to enhance democracy.

Answering the second key question, to whom is an organisation accountable, is difficult in non-owned organisations, for agency theory and stakeholder theory compete. Present-day research tends to utilise stakeholder theory, yet the principal-agent paradigm is strong in the public and nonprofit sectors, often due to contractual arrangements (Broadbent, Dietrich and 
Laughlin, 1996; Cordery et al., 2010; Ebrahim, 2003). Principals' contract with agents to deliver goods and services they need, but also seek to control agents whom principals believe may undertake independent actions that do not meet with their expectations or requirements (Cordery et al., 2010). Accountability becomes a form of control over the agent or subordinate to ensure they perform as required. The ensuing hierarchical accountability relationship (one of control) means that significant funders often seek to control the nonprofit fundee through praise or blame and bestowing rewards and sanctions (Ebrahim, 2003). Such a hierarchical relationship means a strong funder's demands may crowd out the organisation's obligations to other donors, sponsors and service recipients (for examples, see Cordery, et al., 2010; Laughlin, 1996; O'Dwyer and Unerman, 2008; Ebrahim, 2003). This problem tends to be exhibited in nonprofit organisations, (more than in the public sector) because of their relative dependence, their multiple principal-agent relationships and the potential conflicts between principals' interests (Ebrahim, 2003). Conversely, rather than funders alone, control is wielded over public sector agencies by institutions such as "legislatures, statutory authorities and courts" (Mulgan, 2003, p.563).

Stakeholder theory recognises that a wide number of organisations (and individuals) are affected by an organisation, even if the stakeholders are not funders, but receivers or suppliers of goods and services. These stakeholders and organisations have reciprocal rights and obligations (Roberts and Scapens, 1985). That is, public and private nonprofit organisations have an obligation to account, but salient stakeholders also have a right to hold these organisations to account, which results in these reciprocal rights and obligations. The various stakeholders can be classified as upward (hierarchical, as in agency theory) and downward or lateral stakeholders. For example, nonprofit and public sector organisations may be accountable upwards to donors and government and downwards to beneficiaries, staff and other similar service providers. Ebrahim (2003) notes the necessity to prioritise the multitude of stakeholders if organisational accountability is to be discharged effectively.

Roberts (1991) recommends that organisations develop strong downwards and lateral relationships by encouraging shared values and greater trust between different stakeholders and the organisation. While some research in nonprofit organisations has noted that distinguishing between trust-based (lateral and downwards) and agency theory-informed control-based (hierarchical) accountability is difficult (Jacobs and Walker, 2004), it is generally acknowledged that lateral and downwards relationships are less formal and more cooperative than hierarchical accountability relationships (Awio et al., 2011; Cordery et al., 2010; Laughlin, 1996). In the public sector, democracy is enhanced through downwards accountability when it encourages public dialogue leading to a shared set of expectations about goals and objectives (Mulgan, 2003). This is further expanded on in the discussion on mechanisms. By developing trusting relationships with a broad range of stakeholders, nonprofit and public sector organisations can exhibit these lateral and downwards relationships through being proactive rather than reactive, and involving stakeholders in dialogue and debate to agree the values and priorities that should drive their objectives or related strategy (Cordery et al., 2010).

In respect of the third key issue, accountability mechanisms, numerous formal mechanisms of accountability have developed (Ebrahim, 2003; O'Dwyer and Unerman, 2008), including financial and non-financial reporting, Annual General Meetings (AGMs) and other assessments and evaluations (Cordery, 2005; Fowler, 2010; Jones and Pendlebury, 1992; Macias, 2002; Wilson, Kattelus, and Hay, 2001). Participatory processes which are informal forms of accountability ('face-to-face') may fulfil the need for local calling to account, although there have been few studies into the use of this in 'grass roots' organisations. Awio et al. (2011) was an exception. Their research considered NGOs in which local people relied 
on oral accountings which built trust, and the organisations intertwined these informal mechanisms with more formal reporting to discharge accountability. Formal and informal mechanisms therefore comprise not only methods of discharging accountability, but are also externally observable means of the "to whom and for what" aspects of accountability. Further, non-financial communication is likely to provide information that is more useful to discharge accountability for the social objectives of nonprofit and public sector organisations.

In the public sector specifically, concern has been expressed about the need to discharge accountability through processes that also enhance democracy. Mulgan (2003) describes the operation of democracy in ancient Athens, where the popular assembly discussed and agreed on policies and actions. Also, officials' performance of the day-to-day administrative tasks was assessed by the assembly through regular scrutiny and accounting with respect to spending and decision-making. Bovens (2005, pp.192-193) notes, "public account giving, therefore, is a necessary condition for the democratic process", highlighting the role of public meetings to develop trust between public officials and constituents. Nevertheless, Biesta (2004) considers that, in the present day, the democratic potential for accountability in education has been lost. He believes this potential existed some decades ago when accountability was seen as part of mutual responsibility (without providing details). If Biesta (2004) is correct that in the past educational democracy was enhanced by downwards accountability, then we would expect an historical study to show that public sector organisations discharged accountability downwards through mechanisms designed to engage the public. As nonprofit organisations are not expected to develop democracy, we would not expect research to find evidence in them of many democracy-enhancing mechanisms.

Although public and nonprofit organisations share many similarities in accountability theorisations and practices, it would be expected that there would be differences between these types of organisations, particularly in the discharge of public accountability and also in the prioritisation of powerful stakeholders. For example, we would expect that a nonprofit organisation would be more focused on a privately defined mission, yet have multiple (perhaps conflicting) stakeholders to whom they need to account (see, for example, Ebrahim, 2003). These demands for accountability would relate to their mission as well as for donated funds. As such, they would need to discharge accountability through financial and nonfinancial mechanisms. By contrast, a public sector organisation would be legally required to comply with goals that had been decided following a democratic process, with accountability to parliament and electors (the general and tax-paying public) for the achievement of these financial and non-financial goals (see, for example, Mulgan, 2003). Further, the democratic imperative would drive a need for mechanisms that include public meetings and involvement of the electorate in the calling to account (see, for example, Bovens, 2005). These assumptions are presented in Table 1, which also serves as a summary of the theoretical discussion above. 
Table 1: Accountability features of nonprofit and public sector organisations

\begin{tabular}{|c|c|c|}
\hline Focus & Nonprofit (private) & Public sector \\
\hline \multicolumn{3}{|l|}{ For what? } \\
\hline - Overall & $\begin{array}{l}\text { To achieve a mission, privately } \\
\text { defined. }\end{array}$ & $\begin{array}{l}\text { For a public good (agreed } \\
\text { through democratic process); } \\
\text { compliance with bureaucratic } \\
\text { rules. }\end{array}$ \\
\hline - Specifically & $\begin{array}{l}\text { Non-financial and financial } \\
\text { aspects of performance/use of } \\
\text { resources. }\end{array}$ & $\begin{array}{l}\text { Non-financial and financial } \\
\text { aspects of performance/use of } \\
\text { resources. }\end{array}$ \\
\hline To whom? & $\begin{array}{l}\text { Myriad, including donors, grant } \\
\text { makers and other funders, } \\
\text { beneficiaries. }\end{array}$ & Public, parliament. \\
\hline Mechanisms & $\begin{array}{l}\text { Dependent on direction of } \\
\text { accountability \& demands of } \\
\text { stakeholders, whether processes } \\
\text { build trust or exist as a result of } \\
\text { hierarchical control. }\end{array}$ & $\begin{array}{l}\text { Democratic-enhancing } \\
\text { processes where trust is } \\
\text { enhanced; compliance processes } \\
\text { to control workers/organisation. }\end{array}$ \\
\hline
\end{tabular}

While internationally there is a small but growing body of research analyzing accountability relationships and mechanisms in contemporary nonprofit and public sector organisations, many of them using aspects of the accountability framework presented above, there have been few historical analyses of accountability in organisations within and between these two sectors. The following sub-section considers the relevant historical literature.

\subsection{Accountability in nonprofit and public sector organisations: an historical perspective}

Previous publications about accountability relationships and/or mechanisms in the nonprofit and public sector in nineteenth century New Zealand are limited to considering accountability in the public health sector (Van Peursem, Pratt and Tower, 1996), the role of accounting and accountability in religious (nonprofit) organisations before organised settlement (Cordery, 2006), and financing, accounting and accountability in nonprofit education provision in the first few years of colonial settlement (Fowler, 2010). Van Peursem et al. (1996) consider how accountability is influenced by a change to private sector accounting methods through examining external financial reporting by public hospitals in New Zealand between 1872 and 1993 using a political-economic perspective. Initially, they focus on the reforms of 1990-1993 that adopted private sector accounting methods and reporting requirements, and then compare these to reporting requirements under the Public Health Act (1872) and Hospital and Charitable Aid Act (1885). The paper concludes that the financial reporting practices of public hospitals followed the government's health care policy of the time, suggesting a political dimension to public sector accountability practice. Cordery (2006) analyses the accountability discharged by Methodist missionaries prior to organised New Zealand colonisation (1819-1840). The paper describes how distance and prevailing economic conditions could have tempted the missionaries to avoid accountability and other stewardship standards set by the church ethos. It outlines the types of activity performed by these men and the accounting records kept, and indicates the missionaries achieved a degree 
of economic accountability as well as adhering to their mission. The focus of the above research is on the conditions that formed these accounting and accountability systems; they describe organisations' hierarchical relationships and strong hierarchical control. These case studies do not address the situation of organisations facing changes due to gaining different stakeholders or owners.

Fowler (2010) examined in detail the financing and accounting practices utilised between 1842 and 1852, during the formation and development of a colonial New Zealand education system. Her study suggests the main issue associated with the Nelson School Society system was "not the governance of branch committees or the calculability of individuals, but the need to gain approval and resources from the community and associated organisations" (Fowler, 2010, p.341). To do this, the NSS needed to account to its specific stakeholders and the Nelson community at large, building downwards relationships. It is suggested that reporting at the AGM and public oral examinations of students fulfilled some sort of accountability role. However, little detail is provided of for what the NSS was accountable, to whom it was accountable or the mechanisms used to discharge accountability.

A comprehensive search of international publications indicates little research into nineteenth century accountability in a similar educational context. Connelly, Fletcher, and McKinstry (1995) examine the structure, financing, accounting procedures, auditing, financial reporting, and community accountability in Scottish school boards in a later period (between 1872 and 1918). To ensure universal education, the parish-based, but county controlled, Scottish education boards taxed locals and charged students fees, in addition to receiving government grants. Under the 1872 education legislation to provide a sense of local accountability in each area, a system of elected school boards was established. Yet, in order to gain efficiencies, under the Education Act of 1908, these boards were centralised and managed at a county level, allowing greater standardisation and availability of educational expertise. Connolly et al. (1995) suggest the abolition of the parish-based boards resulted in a loss of local downwards accountability.

Sargiacomo and Gomes (2011) argue there is a need for accounting history research into the accounting inter-relationships, in particular the similarities and differences between (local) governments and non-governmental organisations. The limited research in this area indicates there will be differences in the accounting and accountability systems or practices as a result. Examples include a change in accounting due to a shift in control in hospitals from voluntary to state control in the UK between the 1890s and the 1950s (Robson, 2003); a study of hospitals some three centuries (1590-1620) earlier where organisational and accounting system change was as a result of wider political changes as the Dukedom of Ferrara devolved to a Papal State (Vagnoni et al., 2010), and the consolidation of voluntary and local-government run hospitals following the French Revolution (Lacombe-Saboly, 1996) that resulted in the subsequent modification of accounting to suit the organisational structure and aims. In addition, Macias (2002) identifies how accounting and accountability changed as a result of privatisation when government's tobacco interests were sold to a for-profit company. She concludes that "accounting played a central role in both enhancing and changing the nature of accountability" during the shift from public sector to private sector control and that "led to a different form of accountability;" one that focused on economic aspects rather than legal compliance (Macias, 2002, p.340). Nonetheless, how this applies to changes in ownership and control in an educational situation is unknown. The present analysis covers a point in time where relationships changed as the provision and control of primary (elementary) education moved from private nonprofit to public sector organisations. 
Prior historical studies of organisational change have shown a change of accountability emphasis. In contrast to Connolly et al. (1995) and Fowler (2010), the present paper offers an insight into accountability relationships, mechanisms, and changes as responsibility for education in Nelson moved from private nonprofit organisations to a public sector organisation. In doing so, it examines accountability relationships focusing on to whom the education provider was accountable, and for what they were accountable, as well as identifying the non-financial and financial mechanisms used. In particular, it uses accounting records and other similar information to make visible these accountability relationships (as suggested by Quattrone, 2004 and Vagnoni et al., 2010). Archival evidence was collected from: correspondence, diaries, personal papers, minute books, financial records, and the reports from school and centralised inspectors, as well as from government. These records were supplemented with information from other official government documents, legislation, and the newspapers of the day (mainly the 'Nelson Examiner and New Zealand Chronicle' (NEX)). The research differs from Fowler (2010) in that it extends the period analysed to include a period post-provincial government formation, allowing the examination of sectorial similarities and differences. Additionally, it focuses on accountability relationships and mechanisms using an accountability theory lens, which has not been used in prior studies. The results of this research will now be presented.

\section{Accountability in Nelson Education: For what, to whom and the mechanisms used}

Organisations discharge accountability by accounting for their financial and operational activities to external stakeholders (Ebrahim, 2003). In a nineteenth-century New Zealand educational context, these external stakeholders could comprise the government, subscribers, parents, creditors, and the wider community. These people had immigrated to "create a better life for themselves and the majority had no wish to perpetuate the abuses which they had suffered at home" (McKenzie, 1963, p.21). Therefore, in the education systems they founded:

lay the hopes of [these] migrating people, the British element pragmatically impatient with the limitations, imposed by the establishment in church and state and the class conventions of the old layered society (Bailey, 1989, p.2).

The way that education developed in Nelson reflected their hopes, and the manner in which school management discharged their accountability for this "hope" is evidence of the way that they sought to demonstrate their performance to these stakeholders.

In the different periods, when the Nelson schools were operated by the community and then operated as part of the public sector, this paper will show that the accountability arrangements changed in respect of for what and to whom and the various mechanisms used to account to external stakeholders. Accountability was achieved at various times through the presentation of audited financial and other information at public meetings, public examinations, school inspections, and the publication of reports and returns. Each of these will be examined in the next sections.

\subsection{The NSS period (1844-1856): Lateral accountability with some hierarchical aspects}

During the early years of organised Pākehā[3] settlement, the majority of schools in New Zealand were operated by the Anglican, Presbyterian, Roman Catholic, and Wesleyan (Methodist) churches, with a few private establishments run by individuals (Nimmo, 1989). However, in Nelson, the Nelson School Society (NSS) operated alongside the church and other independent schools and was funded similarly through pupil fees, subscriptions, 
government grants, other fundraising activities, and cash and non-cash donations (Fowler, 2010). This research focuses on the NSS as the dominant nonprofit primary level education provider to the Nelson settlement (Fowler, 2010).

The NSS offered non-denominational religious-based education, based on the British and Foreign School Society system.[4] The mission of the NSS was to promote education among all Christian denominations within the Nelson communities (NSS,1848) so that "...the child of every Christian can on common ground meet to partake of its advantages, with no offences to the conscience of any" (NEX, 1854). Between 1844 and 1856 (when its day schools were 'taken over' by the public sector), the NSS expanded from managing a single day school (at Bridge Street, Nelson) to operating a geographically dispersed multi-site system comprising nine day schools (Fowler, 2010). A General Management Committee operated the Bridge Street School, while Branch School Committees operated the other day schools. These Branch Committees were responsible to the General Management Committee and were required to operate in accordance with NSS rules. Committee members came from a variety of occupational backgrounds including gentlemen, farmers, clergy, members of the professions, storeowners, merchants, and mechanics (craftsmen). Additionally, several committee members were contemporaneously involved in Nelson's local government, providing political support for the NSS educational model (Fowler, 2010).

While government was a funder of NSS (see Figure 1), pre-1854 financial contributions from government were minimal and sporadic at best, and could only be conceived as grants to the nonprofit organisation rather than payments for service delivery. In the early stage, the NSS was not a part of the public sector, in contrast to the later Scottish system described by Connolly et al. (1995). Although the Nelson Provincial Government was formed late in 1853, legislation relating to education provision for the Province of Nelson was not introduced until 1856 (as explained in section 3.2).[5] However, from 1854 until the public sector took over the nonprofit schools, the Nelson Provincial Council provided some financial support to nonprofit schools, including the NSS, from public money.

Between 1844 and 1856, as shown in Figure 1 below, the mechanisms used by the NSS to discharge accountability for financial, operational and staff performance to its educational stakeholders were principally public meetings, public examination of pupils, and the preparation and presentation of reports and returns.

\subsubsection{Public meetings, annual reports and related audit processes}

The early NSS school management committees held special public meetings during each year. The primary purpose appears to have been to raise subscriptions to establish schools. Secondary purposes of these public meetings were to elect additional committee members and transact business relating to governance and school management procedures. The meetings were attended by potential subscribers, donors, and representatives from the New Zealand Company and, later, the colonial government (Fowler, 2010). The accountability relationships associated with this mechanism are identified as $A_{1}$ in Figure 1. 
Figure 1: The NSS funding and management system

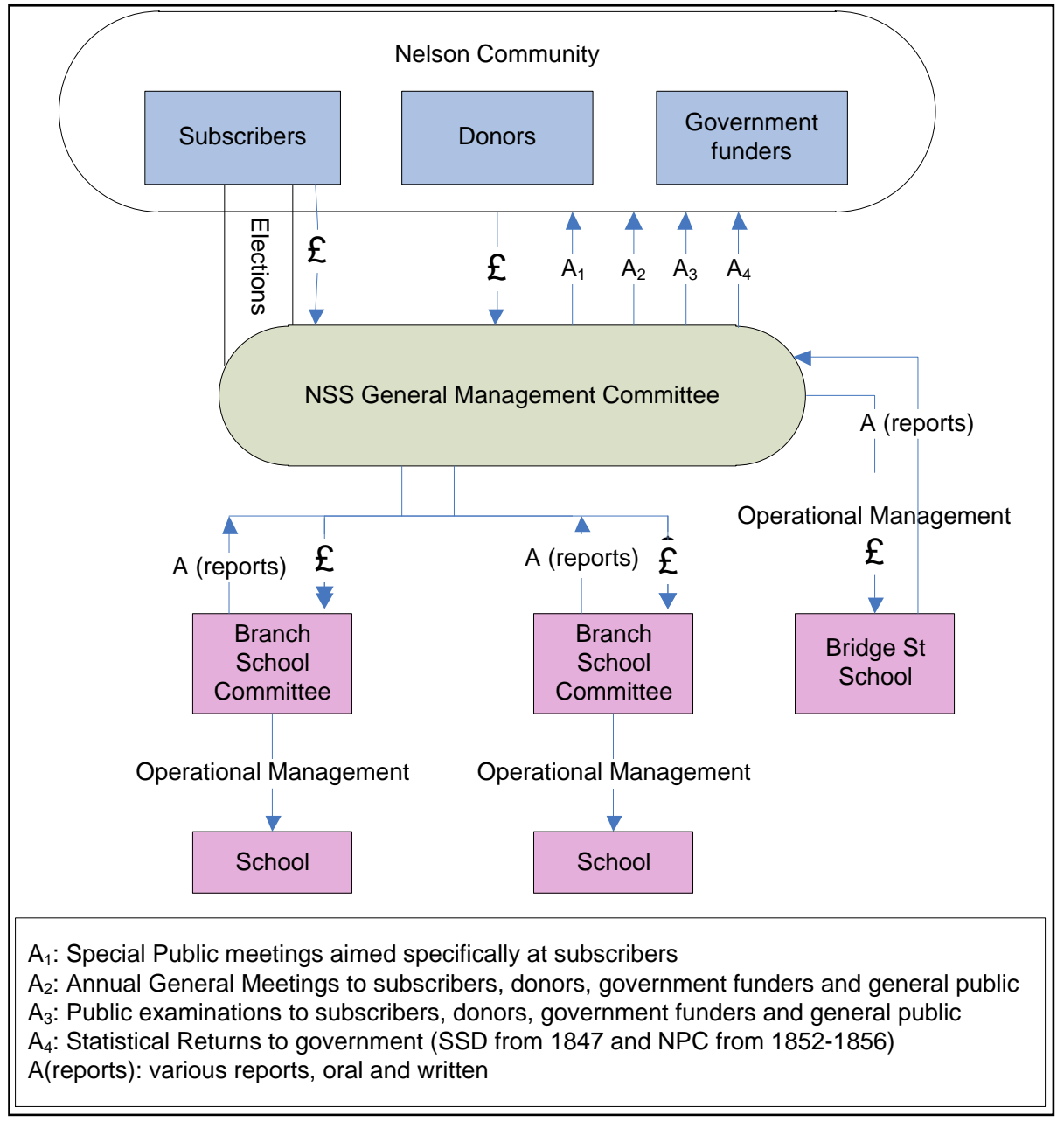

Another public meeting was the public "anniversary" or annual meetings (hereafter AGMs) held by the NSS. These began in 1844 and were held annually on Easter Monday. During an AGM, annual reports (previously read and confirmed at a pre-AGM general committee meeting), were presented to subscribers, donors, government or New Zealand Company representatives and the general public. These AGMs are identified in Figure 1 as $A_{2}$. The pre-AGM meetings were where the NSS accounts were examined and/or audited and balanced. The practice of holding an Easter Monday meeting was formalised in the 1848 Rules and Regulations, written to incorporate the NSS. Rule VIII (1848 Rules and Regulations) states that at the meeting:

An account of the receipts and disbursements for the preceding year, and the proceedings of the Institution shall be stated and a Report for publication agreed upon. Notice shall be previously given, by public advertisement. (NSS, 1848)

This enabled the NSS to receive funding from the Governor (an example of a hierarchical relationship).

Further formalisation is also shown by Rule IX which states "two or more subscribers shall be nominated as auditors of the accounts of the institution" (NSS, 1848). Nevertheless, it appears that until the 1852/1853 financial year the NSS did not fully follow Rule IX as only one person audited the accounts. From the 1852/1853 year two signatures are present, with both being subscribers and in the 1854/55 financial year, for the first time a non-subscriber 
auditor was appointed. A possible reason for the tightening of audit practice during the 1850s was the growth in funding from government sources. From 1850 until 1853, the NSS received a donation or grant of 35 pounds p.a. from the Governor (Fowler, 2010), while between 1854 and 1856 the NSS received a total of 828 pounds from the provincial government or more than five times the total subscriptions or cash donations received from community sources in these years (NP, 1853-1859). As this was money provided from the public purse, improving auditing practice can be seen as a way of demonstrating accountability for the money received from a stakeholder that had become dominant.

The AGM annual reports allowed the NSS to discharge financial and non-financial accountability and contained the following:

1. The condition and operation of schools including pupil attendance, teachers, pupil fees and other payments, the construction of buildings, and establishment of schools.

2. Financial information including audited financial statements (Fowler (2010) provides more detail on the content of the cash-based financial statements of the NSS).

3. A discussion of funding issues, government grants, and the poor financial situation.

For example by the 1850 AGM, the committee had "...much pleasure in being able to report favourably, both as regards financial and education progress", but made an appeal for more funding. They also report, "the numbers of scholars have considerably increased in almost every branch of the institution" (NSS, 1850; NEX, 1850c). Nevertheless, the financial situation was always perilous. Matthew Campbell, as the NSS Treasurer, financed a large portion of the NSS's expenditure. The general management committee paid portions of this liability when it was able (see also Lacombe-Saboly, 1996), with his substantial debt of $£ 555.7$ s.9d being finally settled from public funds in 1859 (NEX, 1859b).

4. In later years, a list of subscribers and each donation that was contributed. These lists were not published in the newspaper, but were publicised at the meeting.

5. Other business conducted by the NSS, including the 1848 Rules and Regulations (NSS, 1848).

The AGM report was normally read by the Secretary and adopted by those present, and trustees (when necessary) and committee members were elected. AGMs were advertised in the newspaper on a community-wide basis beforehand. Copies of the annual reports were recorded in the minute books. Between 1848 and 1856, these annual reports were reproduced, as required, in full in the newspaper along with an announcement of the committee elected for the coming year, which meant the general public could see who was responsible for education in their local community. This can be seen as a way for the general public to potentially hold them to account for the school's performance.

As they formed part of the annual Easter anniversary celebrations, these AGMs were well attended[6]. Due to the high level of attendance, they were used as a platform to promote the necessity of education to the Nelson settlers, which was an opportunity for the NSS to promote its key mission, obtain financial support and to account for its performance over the previous year. As part of this lateral accountability and to build community support (or trust), prominent community members including the clergy, New Zealand Company representatives, and others gave addresses on the value of education. 


\subsubsection{Public examinations}

The public examination of scholars was common practice for the NSS and was conducted by well-educated members of the community. (These are identified in Figure 1 as A3.) Typical subjects examined were scripture, reading, arithmetic, and history. This practice provided a way for parents and other resource providers to hear the performance of the pupils and thus ensure the NSS's mission was being adhered to. Public examination on this scale appears to be an unusual practice in regard to education at that time (although this conclusion is based on the limited research in this area).

Between 1844 and 1852, these examinations occurred at the Easter anniversary celebrations, the annual December assembly of schools and other special occasions. Sometimes, public examinations were conducted at individual branch schools. As part of these special occasions, public (afternoon) teas were held. Admission was charged at one shilling (including refreshments), or one shilling and sixpence when there was also a fireworks display. An advertisement for the 1850 assembly of schools celebrations is reproduced in Figure 2 (NEX, 1850d).

Figure 2: Public tea and special occasion advertisement

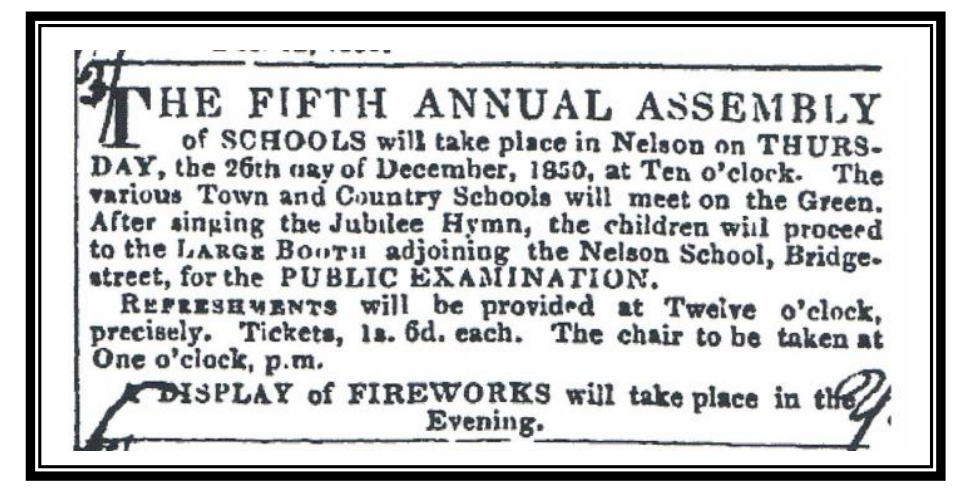

One shilling and sixpence was not an overly expensive price in 1850 as a pair of ladies patent leather shoes was five shillings and sixpence (NEX, 1850a), a dozen eggs were one shilling (twelve pence), and a pound of fresh butter was ten pence (NEX, 1850b).

All the examinations at the NSS Easter anniversary celebrations were advertised except the one in 1848, although the 1848 annual report suggests a public examination took place. Furthermore, in 1848, Governor Grey, and the Bishop of New Zealand (Bishop Selwyn) both examined NSS pupils during their visits (ATL, 1848a and 1848b). At some point in his January 1849 visit, the Governor examined each class individually (NSS, 1849). Later on (in February 1851), the Governor was part of a specially arranged examination of all country, church and NSS schools (NEX, 1851).

These public examinations were also reported on in detail by the newspaper. The examinations were well attended by the general public, for example, in 1849 approximately 550 to 600 children and about one-third of Nelson's population attended (NEX, 1849). Examinations were conducted by the New Zealand Company Agents, ministers, and other prominent community members. For instance, at the Seventh Annual Assembly in 1852 local gentlemen and the clergy conducted the examination and "the children acquitted themselves very creditably both in their examination and singing, and gave great satisfaction to a very large body of persons who were present" (NEX, 1853a). From 1846, the NSS invited other schools to their annual Christmas assemblies with the Wesleyans joining first and, from 1848, pupils from the Anglican schools also attended. There is no record of the church 
schools conducting their own or participating in NSS public examinations after 1853 . However, the NSS examinations continued to be held. The final assembly of the NSS took place in February 1856. The delay from December was so the Governor could be present. The Governor, Nelson Provincial Council members, and others addressed the gathering with the examination being conducted by the Nelson (Bridge Street) Schoolmaster (NEX, 1856a; NEX, 1856b). These public meetings were a matter of pride and can be seen as a way that the NSS could build community support (or trust) in their educational methods, as well as demonstrate that the education practices adopted by them were worthy of continued community support.

\subsubsection{Government reports and statistical returns}

During the crown colony period (1840-1852), the NSS was predominantly accountable to its local communities (the subscribers and donors shown in Figure 1) with limited accountability to government (because of its minimal and sporadic financial support). Nonetheless, the Nelson sub-district (of the Colonial Government) reported on that settlement's education provision to the Colonial Government (identified as A4 in Figure 1) and included information provided to the sub-district by the NSS. This is an example of accountability being 'discharged' before too many resources were committed to the NSS by the colonial government. It could be conjectured that the NSS provided reports to Nelsonbased government officials in order to gain future funding and indicates how NSS engaged government as a stakeholder to whom it appeared to believe it was accountable even without resources being provided.

There were other ways the NSS was reported on to government. Government officials resident in Nelson accounted upwards to the Colonial Government for education provision by nonprofit organisations including the NSS. Examples of the types of government returns include the first official Return of Schools compiled in 1847 by the Superintendent of the Southern Division (based in Nelson), detailing whether day schools were free and their location, the teacher and salary, the number of students, the system of education used, and the income sources (Butchers, 1929). The Superintendent was also required to furnish annual 'Blue Book' returns with the Colonial Secretary. Of 14 statistical items, three (population, schools and a Statement of Revenue and Expenditure) provided information relating to education. Returns included the amount spent on schools as well as the number of schools and scholars, and the location and type.

Once the Nelson Provincial Government was formed in 1853, there was a change in the type of statistical data published and to whom it was provided. The Nelson Provincial Council continued to collect data from education providers (including the NSS) and Council proceedings were published in the newspapers along with select committees reports, bills, and legislation. Many of these proceedings related to primary education provision. For example, one provincial council resolution (23 December 1853) moved that schools provide a return of the number of the scholars attending and also the names of the teachers employed and the salaries they received (NEX, 1853b). The return's purpose was not stated, but probably related to initial debates in council in November and December 1853 regarding the need for public education.

\subsection{The Public Sector Period (1856- ): Hierarchical accountability with lateral remnants}

In 1856, the Nelson Provincial Council fitted a public education system onto the existing structure and took over the NSS day schools, the independent schools, and some church schools. This was the first instance of non-fee paying, secular, and universal education 
funded from public revenue in New Zealand (Nimmo, 1989; Simon, 2000). The Nelson Education Ordinance 1856 (NEO 1856) and subsequent amendments significantly changed the structure and control of education. The objective of the politicians developing the education legislation was to put in place an education system "to promote the intellectual development of the rising generation of the province and to secure its prosperity and progress" as the current education provided was not sufficient for the "intellectual and moral training of the children of the province" (NEX, 1855).

Control of education was transferred to a Central Board of Education (CBE) that employed an inspector and established educational districts. Each of the educational districts was managed by a Local Education Committee (LEC). In a hierarchical relationship, the CBE was responsible to the Nelson Provincial Council for primary education provision by establishing, funding, and reporting on public schools. The funding emanated from provincial revenue appropriations, income from leasing educational land reserves and a household-based education rate (Smith and Fowler, 2008). Therefore, the elected Nelson Provincial Council funded the CBE in order to manage (and delegate the management of) the publicly-funded schools in its care. While the NSS had predominantly utilised meetings and public examinations as accountability mechanisms, the accountability relationships and mechanisms (A) used by the CBE in this new arrangement are shown in Figure 3, and are now described.

Figure 3: The Public Sector funding and management system

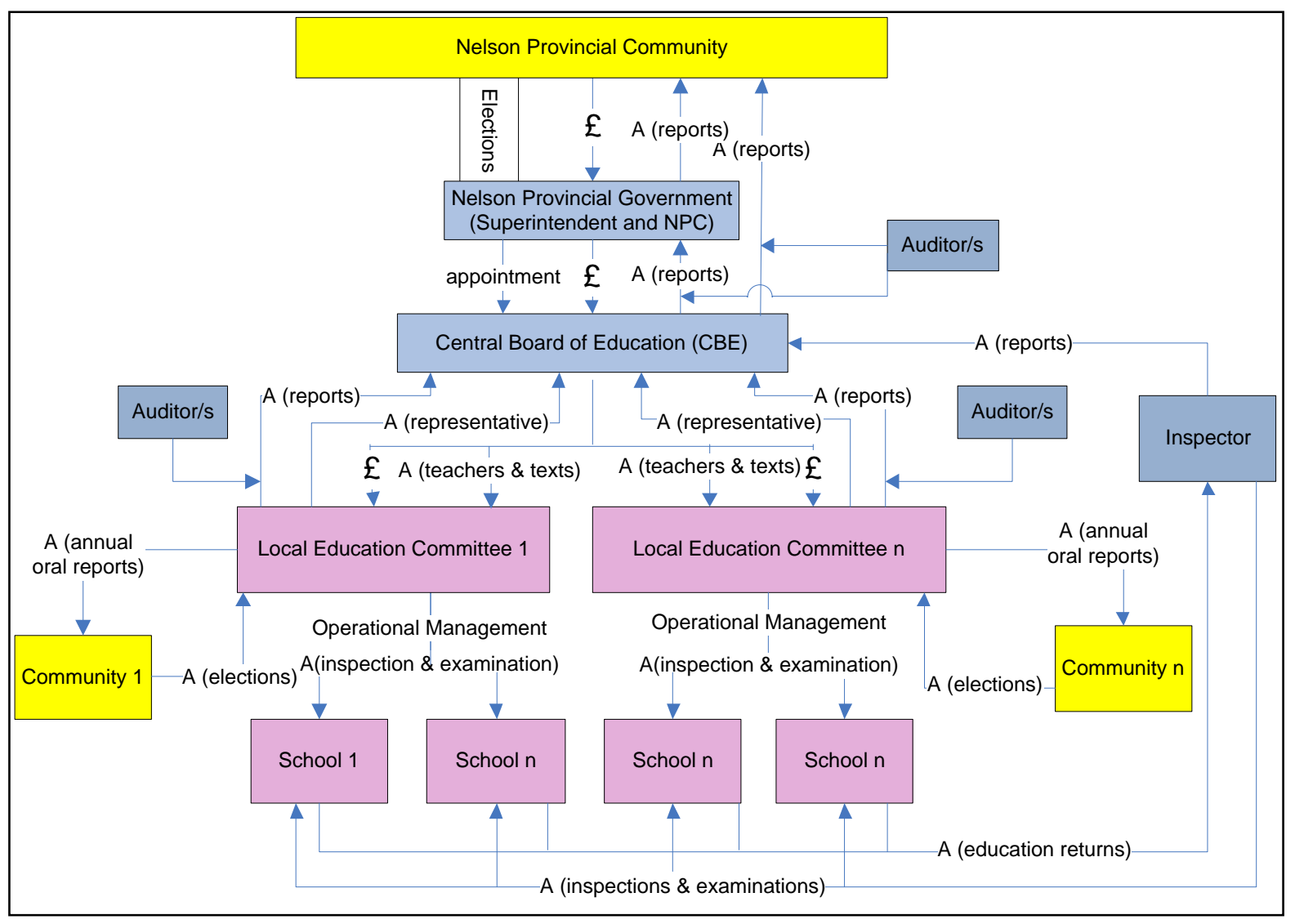

\subsubsection{Meetings, inspection and examination}

The first CBE meeting (21 July 1856) was called by public advertisement (CBE, 1856b; NEX, 1856d). No further advertisements were placed as the CBE bylaws fixed the monthly 
meeting time, although the public was allowed to attend. The CBE included a governmentappointed representative and a nominated representative from each elected LEC (A(representative) in Figure 3). There is little evidence from the names recorded in the minute books that the general public attended these meetings, suggesting that the accountability from this committee was discharged upwards to the Nelson Provincial Council and Superintendent[7], rather than towards the community. This interpretation of the accountability relationship as hierarchical is supported by the fact that the CBE's LEC representative did not need to live in the education district they represented, a practice followed by the LECs in the more remote areas of the Nelson Province.

The LECs, which had been formed to include local input, followed a similar practice of holding monthly evening meetings. Again, there is little evidence that the general public attended these meetings, and one LEC - The Town of Nelson - had to resort to fining its committee members for non-attendance, as they were experiencing difficulties getting a quorum (NLEC, 1856), while other LECs terminated committee membership for being absent, as shown in Figure 4.

Figure 4 Election of new members due to absenteeism (NEX 1861)

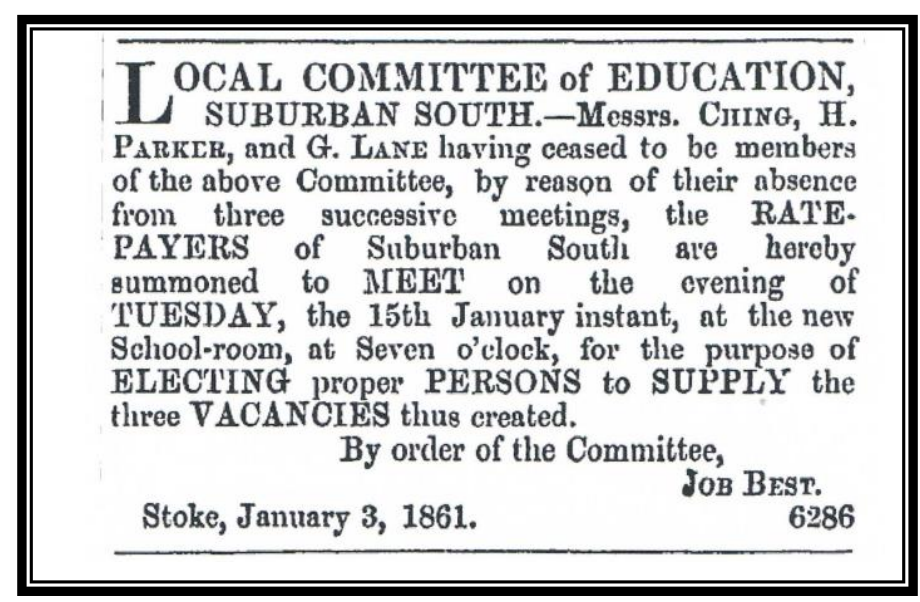

Every June, the LEC held a publicly advertised annual meeting to elect the committee for the coming year and present an annual, probably oral, report to the householders of the education district (NP, 1858) (A(annual oral reports) and A(elections) in Figure 3). There is no evidence these LEC reports were published. Thus, lateral accountability discharge to a wide range of stakeholders (as had occurred previously) is not evident.

Nevertheless, the Nelson Provincial Government itself continued the NSS practice of publishing information relating to education provision, and accounted to the community for public education via the publication in the Government Gazette and newspapers of the halfyearly Inspector and CBE Reports (ending 30 June and 31 December). The CBE reports were legislated for and reported on:

...the condition of the province as regards education, setting forth the number of existing schools, the number of scholars attending these, the course of the instruction pursued in them, and all other such matters as may seem to be of interest and desirable to communicate (NEO, 1856, s21).

The Inspector's half-yearly report to the CBE (as per the bylaws) mostly included a list of each school, gender, days attended, and comparative returns of ages and proficiency of children in public schools. The Inspector also recommended improvements in the 
curriculum, teaching methods, attendance, and administrative practices, and highlighted the need for more funding. Some of this information was based on the quarterly school returns submitted to the Inspector by the schools (A(education return) in Figure 3); the rest was the result of his school inspections and own examination of students, and his own views on education (CBE, 1856a) (A(inspections \& examinations) in Figure 3). Many of his comments were incorporated in the CBE reports (A(reports) in Figure 3). The CBE reports provide a more macro view and discuss issues such as the education rate, Roman Catholic dissatisfaction with the public system, administrative issues, and problems gaining control of the NSS school buildings. The reports recommended possible changes, and incorporated a general discussion on the progress of the public schools and the CBE's satisfaction with the current system.

From these reports, the Nelson community could monitor the behaviour of the elected Nelson Provincial Council, Superintendent, CBE, and LECs, and observe where public funds were spent and the results thereof. Additionally, the CBE mandated the textbooks to be used (often purchasing them for schools) and introduced a requirement for all teachers to hold a competency certificate (issued by the School Inspector) before they could be employed (CBE, 1856c). These legislative or regulatory reporting requirements, and the control over texts and teachers, further emphasise the system of hierarchical accountability relationships from the schools through to the local government.

Even though the CBE had appointed a School Inspector, some of the newly elected LECs continued to publicly examine their scholars, although much less frequently than before. For example, the Town of Nelson's LEC conducted oral examinations in reading, spelling, geography, and arithmetic and written examinations in history and geography. Parents and others interested in education were invited to attend as they had been in the NSS period (NLEC, 1857; Figure 5). A possible reason behind this practice's continuance was that some LEC members were involved in pre-1856 public examinations and saw them as an effective way to account to the inhabitants of the local educational districts for the education being delivered.[8] Prizes were awarded for student achievement in areas such as proficiency, general success, best conduct, most punctual attendance, greatest improvement, and best examination.

Figure 5 Public school examinations (NEX, 1860)

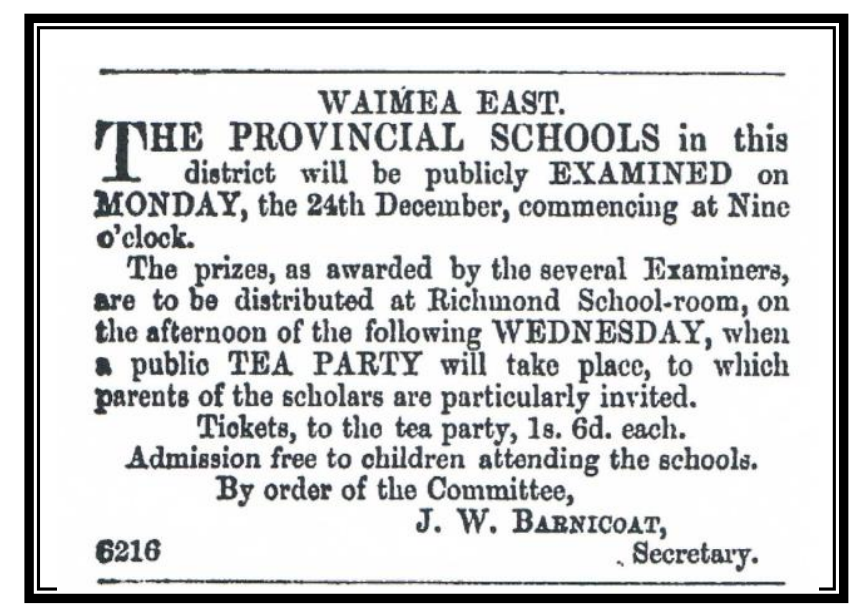

The public examinations were supported by the Inspector who wrote that "the system of examination by the Committees, with the inducements of prizes... wherever they have been adopted, have produced the best results, and I trust will be universally followed" (NEX, 
1858b). The Inspector also encouraged LECs to inspect their schools, a suggestion taken up by at least the Town of Nelson's LEC (NLEC, 1856). Both of these community-focused practices (examinations and inspections) indicate that lateral accountability or accounting to the local community continued in the early years of public sector control but in a somewhat diminished form.

\title{
3.2.2 Financial accounts and audit
}

As shown in Figure 3, the CBE was required to keep financial accounts and have them audited:

\begin{abstract}
All accounts, with all vouchers and papers relating thereto, together with a full abstract or balance sheet thereof, signed by three at least members of the Board, shall, at the end of each year, be audited in the same manner as the public accounts of the province, and a copy of such abstract or balance sheet shall, when audited, be published by the Central Board in some newspaper circulated within the province (NEO, 1856, s20).
\end{abstract}

One supporter of the education ordinance argued that education committees were less likely to misappropriate funds as auditing acted as a guarantee against such behaviour (NEX, 1856c).

Although the CBE was required to have their accounts audited and to publish them, it is unlikely these requirements were met early on. The evidence suggests that early $\mathrm{CBE}$ accounts were not audited before 1858 and that no accounts for the CBE were published before March 1860 (four years after the public sector 'takeover'), thereby failing to meet their legislative accountability requirements. However, once the Provincial Council took control of the education rate (under the Education Amendment Act 1858) it is likely that the CBE accounts were audited as part of the public accounts. This contention is supported by the improving quality of the financial accounts from that time as evidenced in the CBE accounts, the presence of separate accounts from the 1858/59 financial year, and the publishing of the accounts in the Government Gazette and newspaper as part of the CBE reports from 1860. The public accounts were examined and audited half-yearly by a Board of Audit as specified in the Executive Government Ordinance (EGO 1853, s8). The Provincial Superintendent appointed one Board of Audit member and two others were elected by the Nelson Provincial Council from among its members (EGO 1853, s21-s23) producing a degree of audit independence and making the Executive accountable to the elected Council. An independent permanent Provincial Auditor was appointed in 1862. Once the audit process was complete, the public accounts were printed and published.

There is no evidence that the LECs' financial accounts were audited. However, considering the practice of previous school management committees it is probable that auditing occurred. This suggestion is supported by a Nelson LEC minute where after the Secretary reported on the yearly abstract of the accounts, the Chairman was requested to "examine and certify the accounts" (NLEC, 1858).

Overall, the nonprofit education providers had been required to account to their local communities. In contrast, the public education system, as set out by legislation, required elected representatives to account directly to the Nelson Government, which then accounted to their community electors. The next section discusses possible explanations as to why these differences occurred.

\section{Accountability in Nelson Education: differences and similarities}

Within the space of a few years, primary school education in the colonial provincial area of Nelson changed from being provided by private nonprofit organisations, which depended on 
student fees and subscriptions from local families, to being provided by the provincial (local) government and funded by a levy on residents and from other provincial revenue. This brought a number of changes, as summarised in Table 2.

Table 2: Accountability following a change from private nonprofit to public sector provider.

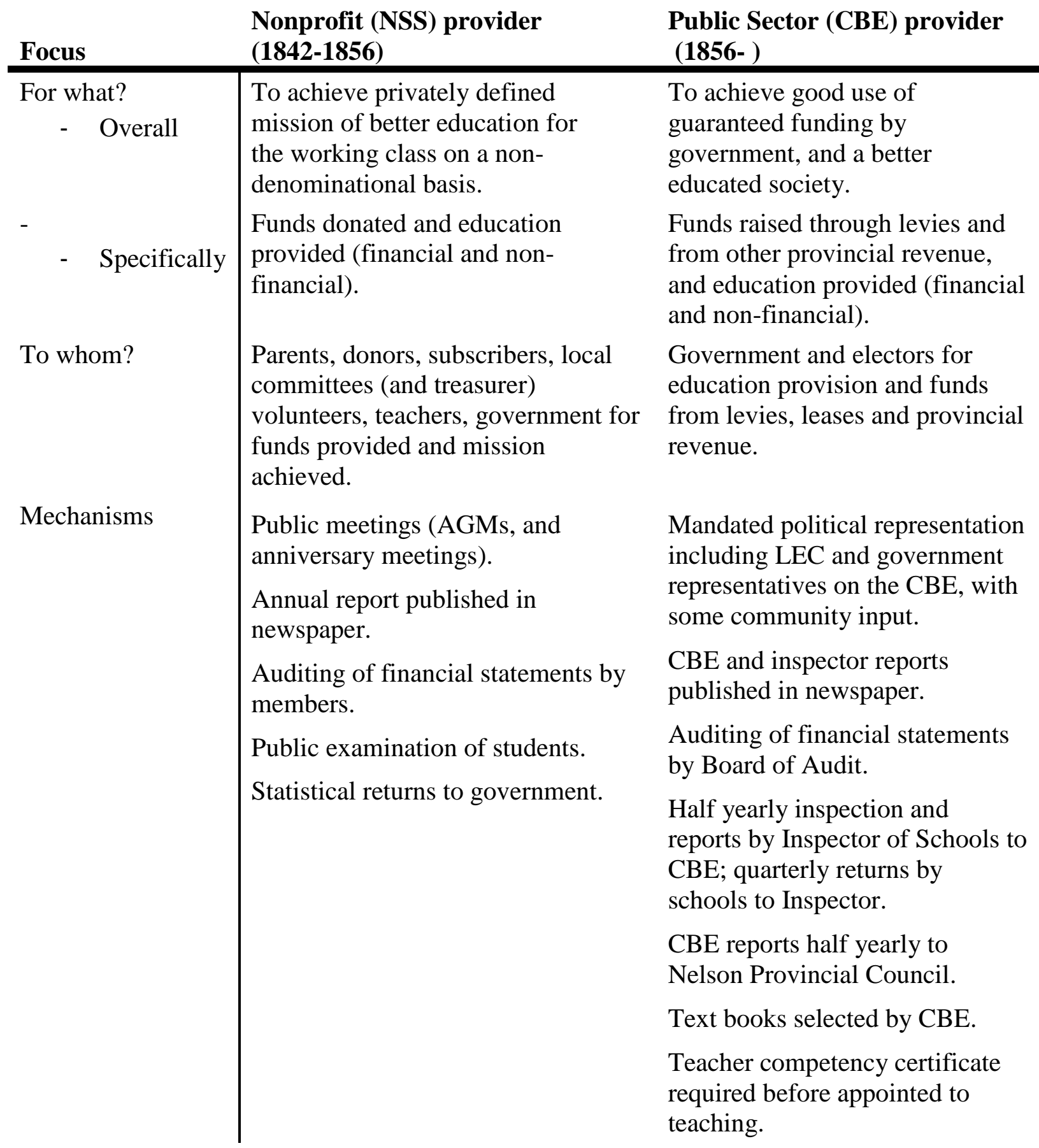

It can be seen from Table 2 that the objective (for what) of the controlling body changed when it moved from being a nonprofit provider to a public sector one. The public sector body was required to report on the use it made of public funds because they had been coercively gathered through levies and from other provincial government activities (a compliance accountability). By contrast, in the nonprofit period, the provider had relied on 
school fees and donations and therefore had to build trust with its donors if it was to continue. In both periods, the provider worked towards a public good of education.

Furthermore, the various types of stakeholders (to whom) became more focused from representing a large cross-section of Nelson society to two: government and (indirectly) those eligible to vote. As can be seen from the mechanisms used, the Government appeared to be prioritised. Several unique accountability mechanisms between school management, the community, and provincial government were lost in the transition from private nonprofit (NSS) to public sector (CBE) schools in Nelson. Some (like the regular anniversary meetings and examinations) had been lateral accountability mechanisms which the NSS utilised to account to their community stakeholders for operational and financial performance (in line with Awio et al., 2011; Cordery et al., 2010; Laughlin, 1996). While the public sector system maintained a community board, reporting to the CBE was centralised through the inspector and the majority of accountability disclosure was upwards to the stakeholder with which the schools had a hierarchical arrangement (as outlined by, for example, Awio et al., 2011; Cordery et al., 2010; Laughlin, 1996). Instead of public meetings to enhance democracy, which the literature (such as Mulgan, 2003) had suggested would be a strong part of public sector accountability, the public sector education provider developed their own mechanisms, focused on compliance, bureaucracy and control.

In addition, the public examination of pupils at celebrations and assemblies was seldom practised after the takeover. Previously an interactive 'festival' atmosphere had imbued the regular public meetings and examinations of the NSS and other nonprofit schools, and this mechanism is likely to have increased trust (as recommended by Roberts, 1991). Under public-sector ownership (CBE), a public sector inspector individually assessed each school. Although the inspection reports submitted to the government were also published for community information, such reports were more formal than the AGMs and public examinations that marked the private nonprofit phase of education provision.

An additional difference between the public and nonprofit sectors highlighted by the literature was the tendency of nonprofit organisations to prefer powerful stakeholders in the discharge of accountability (see, for example Cordery et al., 2010; O'Dwyer and Unerman, 2008). While NSS school trustees included powerful political figures and schools received government grants, the main accountability mechanisms during the nonprofit NSS period were lateral, focused on community, parents, and supporters.

A further difference in the CBE system was that volunteers were no longer a key stakeholder to whom accountability was discharged. The move to a public sector system meant that roles previously held by volunteers (NSS school management and governance) became paid positions, including the Inspector of Schools, Auditor and CBE staff. In addition, due to increased bureaucracy and the CBE's compliance focus, there were numerous complaints about the costs of staff and processing the education rate (Smith and Fowler, 2008).[9] Yet, while the NSS had been dependent on an indulgent Treasurer to fund continuing losses, the provision of education was assured by the input of government money following the public sector takeover.

Nevertheless, Table 2 shows that some accountability mechanisms were similar between the two organisational types, specifically returns and audits. Both the nonprofit NSS and the CBE produced publicly available reports and returns. However, although these were provided voluntarily by the NSS, public sector accountability was principally achieved through legislative and regulatory mechanisms that specified the reports and returns to be submitted and/or published. Further, there is no evidence that the education returns provided by schools under the public sector regime were used by them in their day-to-day 
management, whereas previously the NSS had voluntarily disclosed information they had collected and analysed in their day-to-day operations. In addition, while the examination and/or audit of financial information were common to both organisational types, the degree of formality and the potential quality of the audit performed varied between the two sectors due to the government legislative requirements for public sector accounts to be audited by an independent board.

\section{Discussion and Conclusion}

The nonprofit educational provider presented in this research (the NSS) worked hard to achieve accountability to a great number of external stakeholders through its activities. It utilised public meetings where educational outcomes (knowledgeable pupils) were presented, along with the audited financial statements. Newspaper reports (as the only other available public media) were also important. By using multiple avenues for accountability, it appears that the NSS was able to build trust with its various stakeholders based on shared values for education (as recommended by Roberts, 1991; Awio et al., 2011), as well as demonstrate accountability for its mission (Cordery, 2006; Quattrone, 2004). The NSS effectively utilised the closeness of its community to discharge accountability and gather legitimacy for its cause.

Prior studies have found that strong funders force hierarchical accountability at the expense of downwards accountability (see, for example, Cordery et al., 2010; Laughlin, 1996; O'Dwyer and Unerman, 2008). Yet, the provider in this research had multiple funders: subscribers, donors and government. Only once government funding became the sole source, did hierarchical accountability prevail. Therefore, they needed to build trust with the local communities who were the major funders of the schools (until 1853). This closeness to community also helped to garner further funding; however, it was never enough to make the nonprofit schools financially sustainable.

The types of accountability mechanisms used and their relative importance changed as the provision and control of primary education moved from private nonprofit to public sector organisations. These changes resulted from the change in focus - to define more adequately the public expectations of an education provider and to account for the legality of public sector spending. This compliance focus was also highlighted by Macias (2002). When subsumed into a public sector framework, the schools accounted primarily to their government funder and (similar to the findings in the Scottish study by Connelly et al., 1995) lost the community accountability that had been evident when operating as a private nonprofit enterprise. As public sector organisations, they published statistical and financial returns to discharge accountability, and schools were controlled at a distance using systems including inspection, formal reports and audits. Schools provided lower levels of accountability to individual communities and focused on discharging accountability upwards. This reduced, rather than enhanced, democracy, as the "public account giving" (Bovens, 2005) reduced dramatically.

The history of the NSS also shows that during the private nonprofit phase of the primary schools, the input of supportive community members (parents and leaders) was sufficient for the short-term survival of the school. Yet financial sustainability was never assured. Following the takeover of NSS schools by local government, the risk to the Nelson provincial community of financial failure and educational failure (from unqualified teachers) was lessened considerably. The public sector schools were assured of funding and experienced greater governance scrutiny from inspections, audits and teacher competency 
certification. It is likely that these led to a less problematic school management system, although community engagement suffered.

It is recognised that, as a single case study, the Nelson experience is not necessarily representative of all other historical sites. However, this longitudinal study has yielded rich data which allowed an analysis of accountability across different organisational types and through a period of change. It provides support for prior historical studies (mostly in fields other than education) which have suggested that changes in accountability practices and relationships occur as a result of sectoral change whether from the voluntary or nonprofit sector to the public sector or the public to the private sector (Vagnoni et al., 2010; LacombeSaboly, 1996; Robson, 2003; Macias, 2002). This study identifies the similarities and differences within the accountability mechanisms and relationships between (local) governments and non-governmental organisations in an Anglophone country (Carnegie and Napier, 2012; Sargiacomo and Gomes, 2011). The paper further highlights that trade-offs were made between the types of accountability relationships so that the organisation could achieve financial sustainability.

Further research into the trajectory of accountability would be useful as this system matured. There is also a need for research into the use of democratic accountability mechanisms in nonprofit (private and public) organisations to effectively communicate with disparate stakeholders and to more clearly define the for what and why of accountability. This research has presented unique accountability mechanisms used to enhance democracy, from which to build such research. 


\section{Notes}

[1] Indigenous Māori settled New Zealand from around the $10^{\text {th }}$ century, but Europeans settled only from 1814, and comprised missionaries, whalers and traders. There was no particular organizing government until 1840.

[2] The religious focus of accountability has also been important within other religious communities, for example, in the Jesuit community in the 16th and 17th century (Quattrone, 2004). That paper details the accounting records used and the three systems of accountability that developed (accounting for sins, the College, and the soul).

[3] The European immigrants and their descendants are generally referred to as Pākehā, a Māori word meaning white or foreigner.

[4] The British and Foreign School Society's (BFSS) system was established in England in 1814 and was the successor to the Royal Lancastrian Institution (founded in 1808 by Joseph Lancaster). The BFSS, a voluntary organisation, provided basic education on a nondenominational basis to predominantly the laboring and manufacturing classes (Fowler, 2010).

[5] Nelson and other provincial governments were established by the New Zealand Constitution Act 1852 (NZCA 1852). It created a three-tier government structure comprising a national Legislative Council, the House of Representatives and six provincial governments, that were a form of local government (Bush, 1995). Once created in 1853, provincial governments gradually assumed responsibility for education, with Nelson being amongst the earliest to do so.

[6] For example, over 200 people attended the 1854 annual meeting (NEX, 1854).

[7] The Nelson Provincial Government consisted of the Nelson Provincial Council and the Executive, which was made up of the Superintendent (who convened and presided over the Council), and the Provincial Officers (including the Secretary, Treasurer, Solicitor and Commissioner of Lands).

[8] For example, at the end of 1857, 86 pupils at the Nelson Boys School were examined and more than 200 pupils attended the Monday prize giving for the Nelson Boy's and Girl's school (NEX, 1858a). Also, in 1859 at an examination at Riwaka School, it was reported that 120 children and about 200 adults were present (NEX, 1859a).

[9] This is similar to the Scottish system in the late nineteenth century (1890s onwards), but in that publicly-funded system the community could elect board members to keep the education rate down (Connelly et al., 1995). The process followed in Nelson was that the legislatively-determined, but locally-collected education rate (on citizens) was paid to the CBE (pre-1858) or Provincial Secretary (post-1858) who then passed the money to the Provincial Treasurer. The CBE then drew a warrant on the Provincial Treasurer for the amount of the education rate and the portion of the vote to which they were entitled (Smith and Fowler, 2008). This money was then deposited in the LECs accounts, after deducting the CBE operating expenses and officers' salaries. The problem with this was that at "...each stage of this process, minutes, cheques, receipts, and vouchers are required to make the transaction regular" (NEX, 1858b), increasing administration costs and creating funding delays. 


\section{References}

ATL (1848a), Nelson School Society Papers (Micro-MS-0782), Alexander Turnbull Library (ATL) Collection, National Library, Wellington, Governor's Visit to NSS School, February.

ATL (1848b), Nelson School Society Papers (Micro-MS-0782), Alexander Turnbull Library (ATL) Collection, National Library, Wellington, Bishop's Visit to NSS School, April.

ATL (1854), Nelson School Society Papers (Micro-MS-0782), Alexander Turnbull Library (ATL) Collection, National Library, Wellington, NSS Annual Report, April.

Awio, G., Northcott, D., \& Lawrence, S. (2011). "Social capital and accountability in grass-roots NGOs: The case of the Ugandan community-led HIV/AIDS initiative", Accounting, Auditing \& Accountability Journal, Vol.24 No.1, pp. 63-92.

Bailey, C.L. (1989), A Documentary History of New Zealand Education. Part One: The Imperial Background to New Zealand Education - British Traditions, Government Policies, Colonial Experience 1400-1870, New Zealand Council for Educational Research, Wellington.

Biesta, G.J.J. (2004), "Education, Accountability, and the Ethica Demand: can the democratic potential of accountability be regained?". Educational Theory, Vol. 54 No. 3, pp.233-250.

Bovens, M.A.P. (2005), "Public Accountability". In E. Ferlie, L. Lynne and C. Pollitt (Eds.), The Oxford Handbook of Public Management, Oxford University Press, Oxford, pp.182-208.:

Broadbent, J. and Guthrie J. (1992), "Changes in the Public Sector: A Review of Recent "Alternative" Accounting Research", Accounting, Auditing and Accountability Journal, Vol. 5 No. 2, pp. 3-31.

Bush, G.W.A. (1995), Local Government and Politics in New Zealand, Auckland University Press, Auckland.

Butchers, A.G. (1929), Young New Zealand: A History of the Early Contact of the Maori Race with the European and the Establishment of a National System of Education for both Races, Coulls Somerville Wilkie, Dunedin.

Carnegie, G. and Napier, C. (2012), "Accounting's past, present and future: the unifying power of history", Accounting, Auditing and Accountability Journal, Vol.25 No. 2, pp. 328-369.

CBE (1856a), Draft Bylaws of the Central Board of Education 1856, Nelson Province (NP) series 18/2 Board of Education Reports, Archives New Zealand/Te Rua Mahara o te Kāwanatanga, Wellington

CBE (1856b), Minute Book of the First Board of Education (1856-1867), Nelson Education Board Files (ABDW W3572 Box 26), Archives New Zealand/Te Rua Mahara o te Kāwanatanga, Wellington, Minute dated 14 July.

CBE (1856c) Minute Book of the First Board of Education (1856-1867), Nelson Education Board Files (ABDW W3572 Box 26), Archives New Zealand/Te Rua Mahara o te Kāwanatanga, Wellington, Minute dated 5 September.

Connelly, P., Fletcher, M. and McKinstry, S. (1995), "Educational Accounting, Accountability and Accountants in the era of the 'Scotch' School Boards, 1872-1918", Accounting, Business and Financial History, Vol.5 No. 3, pp. 289-307.

Cordery, C.J. (2005), "The Annual General Meeting as an Accountability Mechanism”, Working Paper no. 23, Centre for Accounting, Governance and Taxation Research Working Paper Series, Victoria University of Wellington, Wellington, New Zealand.

Cordery, C. (2006), "Hallowed Treasures: Sacred, Secular and the Wesleyan Methodists in New Zealand 1819-1840", Accounting History, Vol.11 No. 2, pp. 199-220.

Cordery, C.J., Baskerville, R.F. and Porter, B.A. (2010), "Control or collaboration? Contrasting accountability relationships in the primary health sector", Accounting, Auditing and Accountability Journal, Vol.23 No. 6, pp.793-813.

Ebrahim, A. (2003), "Making sense of accountability: conceptual perspectives for northern and southern nonprofits", Nonprofit Management and Leadership, Vol.14 No.2, pp. 191-212 
Fowler, C. (2010), "Financing, accounting and accountability in colonial New Zealand: The case of the Nelson School Society (1842-1852)", Accounting History, Vol.15 No.3, pp. 337-369.

Jacobs, K., \& Walker, S. P. (2004), "Accounting and accountability in the Iona Community", Accounting, Auditing \& Accountability Journal, Vol.17 No.3, pp. 361-381.

Jones, R. and Pendlebury, M. (1992), Public Sector Accounting, $3^{\text {rd }}$ edn, Pitman, London.

Lacombe-Saboly, M. (1997), "Hospital accounts and accounting systems: a study in the French region of Toulouse from the seventeenth to the nineteenth century", Accounting, Business and Financial History, Vol.7 No.3, pp. 259-80.

Laughlin, R. (1996), Principals and higher principals: accounting for accountability in the caring professions. In R. Munro \& J. Mouritsen (Eds.), Accountability: Power, Ethos and the Technologies of Managing (pp. 225-244). London: International Thomson Business Press.

Macias, M. (2002), "Ownership structure and accountability: the case of the privatization of the Spanish tobacco monopoly, 1887-96", Accounting, Business and Financial History, Vol. 12 No. 2, pp. 317-345.

McKenzie, J.D. (1963), Education in the Cook Strait Settlements, 1844-1856, MA thesis, Victoria University of Wellington.

Mulgan, R. (2003), Holding Power to Account: Accountability in Modern Democracies, Basingstoke: Pelgrave.

NLEC (1856) Town of Nelson Local Education Board Minute Book (1856-1869), Nelson Education Board Files (ABDW W3572 Box 76), Archives New Zealand/Te Rua Mahara o te Kāwanatanga, Wellington, Minute dated 22 September.

NLEC (1857) Town of Nelson Local Education Board Minute Book (1856-1869), Nelson Education Board Files (ABDW W3572 Box 76), Archives New Zealand/Te Rua Mahara o te Kāwanatanga, Wellington, Minutes dated 2 November and 6 December.

NLEC (1858), Town of Nelson Local Education Board Minute Book (1856-1869), Nelson Education Board Files (ABDW W3572 Box 76), Archives New Zealand/Te Rua Mahara o te Kāwanatanga, Wellington, Minute dated 25 June.

NEX (1849), Nelson Examiner and New Zealand Chronicle, 29 December, p. 174.

NEX (1850a), Nelson Examiner and New Zealand Chronicle, 2 March, p. 2.

NEX (1850b), Nelson Examiner and New Zealand Chronicle, 6 April, p. 22.

NEX (1850c), Nelson Examiner and New Zealand Chronicle, 13 April, p. 27.

NEX (1850d), Nelson Examiner and New Zealand Chronicle, 21 December p. 169.

NEX (1851), Nelson Examiner and New Zealand Chronicle, 15 February, p. 202.

NEX (1853a), Nelson Examiner and New Zealand Chronicle, 1 January, p. 178.

NEX (1853b), Nelson Examiner and New Zealand Chronicle, 31 December, pp. 5-7.

NEX (1854), Nelson Examiner and New Zealand Chronicle, 22 April, p. 5.

NEX (1855) Nelson Examiner and New Zealand Chronicle, 8 September, p. 2.

NEX (1856a), Nelson Examiner and New Zealand Chronicle, 30 January, p. 2.

NEX (1856b), Nelson Examiner and New Zealand Chronicle, 2 February, p. 2.

NEX (1856c), Nelson Examiner and New Zealand Chronicle, 18 June, p. 2.

NEX (1856d), Nelson Examiner and New Zealand Chronicle, 16 July, p. 2.

NEX (1857), Nelson Examiner and New Zealand Chronicle, 20 June, p. 4.

NEX (1858a), Nelson Examiner and New Zealand Chronicle, 6 Jan 1858, p. 2

NEX (1858b), Nelson Examiner and New Zealand Chronicle, 10 February, pp. 3-4.

NEX (1859a), Nelson Examiner and New Zealand Chronicle, 5 Jan 1859, p. 2.

NEX (1859b), Nelson Examiner and New Zealand Chronicle, 18 May, p. 2.

NEX (1860), Nelson Examiner and New Zealand Chronicle, 19 December, p. 2. 
NEX (1861), Nelson Examiner and New Zealand Chronicle, 5 January, p. 2.

New Zealand Year Book (1990), New Zealand Official 1990 Yearbook, $94^{\text {th }}$ edition, Department of Statistics, New Zealand.

Nimmo, J. (1989), End of an Era: A Short History of New Zealand Education Boards, New Zealand Education Boards Association, Wellington.

NP (1853-1859), Account Book of Expenditure of Votes 1853-1859, Nelson Province (NP) series 21/11, Archives New Zealand/Te Rua Mahara o te Kāwanatanga, Wellington.

NP (1858), Superintendent General Letters (1858-1859), 29 Jun 1858, Nelson Province Series 7/3a, Superintendent's General Inwards Correspondence, 2 January to 31 December 1858, Archives New Zealand/Te Rua Mahara o te Kāwanatanga, Wellington.

NSS (1848), NSS Minute Book (1844-1855), Nelson School Society (NSS) Records, (B415-Bett Collection), Nelson Provincial Museum Nelson, Rules and Regulations of the NSS, Minute dated 12 July.

NSS (1849), NSS Minute Book (1844-1855), Nelson School Society (NSS) Records, (B415-Bett Collection), Nelson Provincial Museum Nelson, Fifth Report of NSS, Minute dated 13 June.

NSS (1850), NSS Minute Book (1844-1855), Nelson School Society (NSS) Records, (B415-Bett Collection), Nelson Provincial Museum Nelson Sixth Annual Report of NSS, Minute dated 2 April.

O'Dwyer, B., \& Unerman, J. (2008), “The paradox of greater NGO accountability: A case study of Amnesty Ireland", Accounting, Organizations and Society, Vol.33 No.7/8, pp. 801-824.

Quattrone, P., (2004). "Accounting for God. Accounting and Accountability Practices in the Society of Jesus (Italy, 16th-17th centuries)", Accounting, Organizations and Society, Vol.29 No. 7, pp. 647683.

Roberts, J. and Scapens, R. (1985), "Accounting Systems and Systems of Accountability understanding accounting practices in their organisational contexts", Accounting, Organizations and Society, Vol.10 No. 4, pp. 443-456.

Roberts, J. (1991), "The possibilities of accountability", Accounting, Organizations and Society, Vol.16 No.4, pp. 355-368.

Robson, N. (2003), "From voluntary to state control and the emergence of the department in UK hospital accounting", Accounting, Business \& Financial History, Vol.13 No.2, pp. 99-123.

Sargiacomo, M. and Gomes, D. (2011), "Accounting and accountability in local government: Contributions from accounting", Accounting History, Vol.16 No.3, pp. 253-290.

Simon, J. (2000), "Education Policy: Historical Perspectives", in J. Marshall, E. Coxon, K. Jenkins and Jones, A. (Eds.), Politics, Policy, Pedagogy: Education in Aotearoa/New Zealand, Dunmore Press, Palmerston North, pp. 25-68.

Smith A., and Fowler, C. (2008), "Can a Poll Tax Ever be Acceptable? - Evidence from Colonial New Zealand", No. 59, Centre for Accounting, Governance and Taxation Research Working Paper Series, Victoria University of Wellington.

Vagnoni, E, Bracci, E and Maran, L. (2010), "Saint Anna's Hospital in Ferrara, Italy: Accounting and organizational change during the devolution", Accounting History, Vol. 15, No. 4, pp. 463-504.

Van Peursem, K.A., Pratt, M.J. and Tower, G. (1996), "Reporting for the New Zealand Health Sector: A History of Public or Private Interest?", Accounting, Business and Financial History, Vol.6 No. 2, pp. 183-201.

Wilson, E.R., Kattelus, S.C. and Hay, L.E. (2001), Accounting for Governmental and Nonprofit Entities, $12^{\text {th }}$ edn, McGraw-Hill, New York. 